\title{
Effects of cattle rustling and household characteristics on migration decisions and herd size amongst pastoralists in Baringo District, Kenya
}

\author{
George K Kaimba', Bernard K Njehia ${ }^{2,4}$ and Abdi Y Guliye ${ }^{3^{*}}$
}

* Correspondence: guliye@egerton. ac.ke

${ }^{3}$ Department of Animal Sciences, Egerton University, P. O. Box 53620115, Egerton, Kenya

Full list of author information is available at the end of the article

\begin{abstract}
Pastoral communities in arid and semi-arid lands (ASALs) of Kenya depend on livestock for their livelihood. However, these ASALs are characterized by temporal and spatial climatic variation, making availability of resources uneven. Mobility is a key strategy used by pastoralists to efficiently utilize available resources, notably pasture and water. This strategy is being interrupted by a vicious cycle of livestock rustling/raiding. This study was conducted to elucidate the effects of livestock rustling and other household characteristics on migration decisions and herd size amongst pastoralists in Baringo District in Kenya. A sample of 110 pastoralists were interviewed using a structured questionnaire. Binary probit model was used to explain the probability of migrating while ordinary least square was used to explain effects on herd size.

Gender and age of the household head are significant $(P<0.1$ and $P<0.05$, respectively) determinants of migration, whereas both also significantly $(P<0.1)$ influenced herd size. Intensity of rustling, and loss of livestock to drought and/or disease also significantly $(P<0.01)$ influence the decision to migrate. Level of education had significant $(P<0.1)$ and negative influence on herd size, whereas size of household had significant $(P<0.01)$ and positive impact on herd size. Nonlivestock income had significant $(P<0.05)$ and negative influence on migration and herd size.

The practice of livestock rustling, rampant amongst pastoralist communities in Kenya and sometimes occurs across borders, influences pastoralists' decision to migrate and also their herd sizes. It destabilizes communities and undermines their normal livelihood strategies, thus contributing to increased poverty. Increasing the level of development in pastoral areas and formulation of appropriate policies will help in controlling the rustling menace.
\end{abstract}

Keywords: cattle rustling, migration, herd size, Baringo, Kenya

\section{Springer}

@ 2011 Kaimba et al; licensee Springer. This is an Open Access article distributed under the terms of the Creative Commons Attribution License (http://creativecommons.org/licenses/by/2.0), which permits unrestricted use, distribution, and reproduction in any medium, provided the original work is properly cited. 


\section{Introduction}

More than $80 \%$ of the total land area in Kenya consists of arid and semi-arid lands (ASALs) (Okoti et al. 2004), where constraining rainfall and temperature conditions provide limited options for sustainable land use, other than mobile livestock rearing. Mobility is the underlying strategy in the utilization of ASALs (Behnke and Scoones 1993), as it enables efficient use of rangeland resources through seasonal migration in search of pasture, water and mineral licks. Thus, seasonal movement and nomadic pastoralism are the major economic activity and the main source of livelihood for the inhabitants of ASALs. Kenya's ASALs support more than 30\% (approximately 12 million) people, 50\% cattle, 70\% sheep and goats, and the entire camel population (SRA 2003). It is estimated that the livestock sector provides almost $90 \%$ of employment and more than $95 \%$ of family incomes in Kenya's ASALs (FAO 2004).

Livestock plays multiple roles in the lifestyle of pastoralists in Kenya, notably as livelihood sources, socio-cultural and religious functions, and asset and security against risks (Guliye et al. 2007). For example, livestock is the main source of food by providing milk and meat, the basis of traditional social relations, e.g. payment of dowry (from the groom's family to the bride's family) during marriage or compensation of injured parties in tribal feuds, symbol of prosperity and prestige, store of wealth, and security against drought, disease and other calamities.

The pastoralists in Baringo District of Kenya are mainly transhumance pastoralists, and they exemplify communities in ASALs that are dependent on livestock for their livelihood. Traditionally, they move seasonally from their home bases and drive their herds to places with pasture and water and come back to their homesteads in other seasons when pasture improves. Of all the livestock kept by the Baringo pastoralists, cattle are regarded highly. Because of the importance attached to cattle, there is a tendency to accumulate them even under unfavourable environmental conditions, often exerting a lot of pressure on the meagre range resources, notably pasture and water. Inevitably, there is competition amongst pastoralists in the district for the available range resources, necessitating frequent livestock movements within the range in search of pasture and water (Raikes 1981). The occurrence of frequent droughts in ASALs, perhaps a manifestation of climate change, contributes to range resource shortages, leading to intense competition for the available pasture and water. Thus, mobility remains the key pastoral risk management strategy during times of pasture and water shortage. (Little et al. (2001)) point out that pastoralists who migrate with their herds during climatic disasters have considerably fewer livestock losses than those who do not. However, this mobility in itself causes conflict among the pastoralists due to competition for scarce pasture and water.

Pasture and water conflicts have long been part of the socio-cultural pattern of the pastoral communities in Kenya. The communal land ownership tenure system mostly evident in pastoralist areas provides everyone an equal right of exploiting the resources. The lands are traditional tribal grazing areas, such that migration in search of pasture and water by one tribe into areas that belong to other tribes often causes conflict between pastoralists. Besides, livestock movements into grazing lands and watering points that stretch into crop-growing areas also result in conflicts (Dietz 1987). Over time however, pasture and water around the settled areas steadily decreases, leading to emaciation and loss of livestock. Traditionally, whenever scarcity of pasture and water 
or disease depleted a community's livestock, it often sought to replenish numbers through raiding/rustling (Mkutu 2000).

Livestock rustling/raiding, commonly referred to as cattle rustling in Kenya, involves forceful acquisition of livestock (mainly cattle) and is quite common amongst pastoralists in the ASALs of Kenya. Traditionally, cattle rustling often involved small-scale violence and theft of the best livestock or replacement of animals lost through drought or disease. Loss of human lives was rare, and when this occurred, compensation in the form of cattle was paid by the killers' families to the victims or their families in case of death. However, in recent years, due to proliferation of small arms and commercialization of cattle rustling, there is an emergence of large-scale violent cattle raiding between neighbouring pastoral communities in Kenya (Hendrickson et al. 1996). Moreover, there is an emergence of commercialized cattle rustling where wealthy businessmen, politicians, traders or local people pursuing economic objectives finance raids among the pastoral communities. This greatly interferes with the future and assets of the pastoralists. Consequently, pastoral communities arm themselves for protection against hostile groups. The threats caused by the increasing numbers of human deaths and livestock losses due to cattle rusting and other organised raids probably influences the pastoralists' mobility and/or their migratory decisions as well as herd size, thereby undermining their asset base and livelihood sources. Thus, besides lack of pasture and water, pastoralist migration could also be influenced by the perceived threats of cattle rusting and the insecurity generated by it (Doss et al. 2008). There is little information on the influence of cattle rustling on migration decisions and herd size of the pastoralists. This study therefore investigated the effects of cattle rustling and other household characteristics on decisions to migrate and herd size amongst pastoralists in Baringo District, Kenya.

\section{Materials and methods}

\section{Study area}

The study was conducted in Baringo, one of the arid and semi-arid districts in the Rift Valley Province of Kenya. It is located between latitudes $35^{\circ} 30^{\prime}$ and $36^{\circ} 30^{\prime}$ East and latitudes $00^{\circ} 10^{\prime}$ South and $00^{\circ} 140^{\prime}$ North, and covers an area of $10,949 \mathrm{~km}^{2}$, of which about $165 \mathrm{~km}^{2}$ is surface water. The district is hot and dry throughout most of the year. Rainfall is highly variable, with an annual mean of $635 \mathrm{~mm}$, with weak bimodal peaks recorded from March to May and June to August. The average minimum and maximum temperatures are $20^{\circ} \mathrm{C}$ and $35^{\circ} \mathrm{C}$, respectively. The district is characterised by bare ground and loose sandy loam soil with occasional stones on the surface. Much of the vegetation in the area is Acacia woodland dominated by Acacia tortilis, Acacia reficiens and Boscia corriacea. Other major plant species include Balanites aegyptiaca, Maerua angolensis, Cordia sinensis and Salvadora persica. The district is inhabited by the Pokot, Tugen and Njemps communities whose major occupation is livestock keeping.

\section{Sampling procedure}

The sample population consisted of herders within Baringo District. Data were obtained using multi-stage sampling method. Purposive sampling was used to select the rustling/raiding prone divisions in the district which include Tangulbei, Nginyang, Marigat, Kallowa and Bartabwa. The selected divisions were used as study clusters (first-stage cluster sampling). Thereafter, locations, within the cluster divisions, were 
selected at random (second-stage cluster sampling). Then, random samples within each location were selected (third-stage cluster sampling), from which interviews were conducted by use of a structured questionnaire. Herders were asked questions about their household characteristics, herd composition, and the level and effects of cattle rustling in the last 5 years. A total of 110 households were selected for interviews from the sampling frame. Secondary data relevant to the study were also obtained and used in the analysis.

\section{Theoretical framework}

This study is based on the theory of risk and uncertainty. It utilizes the possibilities offered by the Dempster-Shafer theory of evidence as one way of representing imprecise probabilities and partial information in an involuntary decision-making context (Ducey 2001). Pastoral risk management involves making choices/decisions in the face of uncertainties. Most of such choices/decisions, including migratory decisions, involve everyday directly perceptible risks. Such risks are managed instinctively and intuitively (Adams 1999). Risk is restricted to situations where probabilities are allocated to the occurrence of an event. On the other hand, uncertainty arises when the chances governing stochastic factors are imperfectly known. In this case, a herder contemplating a decision at the height of cattle rustling would be likely to face both risk and uncertainty. Just like in many other forms of risks, there is no formal probabilistic assessment done before making a decision to migrate by a pastoralist herder. However, there are two things that are obvious under such circumstances. First, herders prefer higher social economic status in the community to lower status. Secondly, under uncertainty all herders face the possibility that they would suffer heavy losses, and each must compare what he has to gain against what he has to lose in what would be essentially a random draw. Therefore, decisions made due to risk and uncertainties like the fear of cattle rustling or loss of livestock through drought should be able to contend with chances and degree of belief (Ducey 2001). As (Shafer (1976)) points out, if the chance associated with an event is known, it would be advantageous to adopt those chances as degree of belief and act accordingly. (Caselton and Luo (1992)) recommended the utility of Dempster-Shafer theory in decision analysis under risk and uncertainty, particularly where data are sparse and absent.

\section{Empirical model}

The decision of the $i$ th herder to migrate depends on unobservable utility index that is determined by the explanatory variables:

$$
y_{i}^{\bullet}=\beta_{0}+\sum_{j=1}^{k} \beta_{j} \chi_{i j}+u_{i}
$$

From Equation 1, the index function can further be expressed as:

$$
\begin{aligned}
& y_{i} *=\beta_{0}+\beta_{1} x_{1 i}+\beta_{2} x_{2 i}+\ldots+\beta_{k} x_{k i}+u \\
& y_{i} * \text { is unobservable but } y_{i}=\left\{\begin{array}{l}
0 \text { if } y_{i} *<0 \\
1 \text { if } y_{i} * \geq 0
\end{array}\right.
\end{aligned}
$$

where $y^{*}$ is a latent variable which is not observed and only the outcome $y_{i}$ (defined as below) is observed. $\beta_{0}$ is a constant and $\beta_{j}$ are vectors of coefficient to be estimated. 
The $\chi_{k i}$ are the independent variables influencing herder $i, k$ are attributes influencing herder $i$ and $u_{i}$ is the error term.

\section{Model specification}

A herder contemplating whether to migrate would have to evaluate whether the venture is worth undertaking or not. The herder's choice would be based on a set of parameters or attributes (not necessarily in monetary terms) which describe the suitability of migrating. If $\mathbf{X}$ represents a vector of determinants of the decision to migrate, the basic form of the binary probit function with $\check{Z}$ as the predictor variable can be expressed as:

$$
\check{Z}=\beta_{0}+\beta_{1} \mathbf{X}_{1}+\beta_{2} \mathbf{X}_{2}+\ldots \ldots+\beta_{j} \mathbf{X}_{j}
$$

The decision-making process in this case is unobserved and only the outcome, which is migration, is observable. The probability that herder $i$ would choose to migrate can be predicted as:

$$
M_{\mathrm{wl}}=f\left(\mathrm{GHH}^{i}, \mathrm{AG}^{i}, \mathrm{ED}^{i}, \mathrm{HHS}^{i}, \mathrm{NLI}^{i}, \mathrm{CARUINTY}^{i} \mathrm{NCA}^{i}, \mathrm{RSG}^{i}, \mathrm{LO}^{i}, \mathrm{AR}^{i}, \mathrm{BC}^{i} \mathrm{P}_{\mathrm{mmd}^{i}}\right)
$$

where $\mathrm{GHH}^{i}$ represents gender of the household head, $\mathrm{AG}^{i}$ represents age of the household head, $\mathrm{ED}^{i}$ represents education level of the household head measured in terms of number of years in school, HHS ${ }^{i}$ represents the size of the household, CAR$\mathrm{UINTY}^{i}$ is a dummy variable representing cattle rustling intensity in the area, $\mathrm{NLI}^{i}$ is the non-livestock income received by herder $i, \mathrm{NCA}^{i}$ is the number of cattle owned by herder $i, \mathrm{RSG}^{i}$ is the ratio of sheep and goats to cattle owned by herder $i, \mathrm{LO}^{i}$ is a dummy variable representing type of land ownership by herder $i, \mathrm{AR}^{i}$ is a dummy variable representing whether a herder has lost livestock to cattle rustlers or not, $\mathrm{P}_{\text {mmd }}{ }^{i}$ is a dummy variable representing herder $i$ 's perception on migration and $\mathrm{BC}^{i}$ is a vector of biophysical characteristics (disease/parasites and drought/famine).

To model the impacts of cattle rustling and migration decision on herd size, the study estimated a herd size function using the production function approach as simplified by (Kabubo-Mariara (2003)). Kabubo-Mariara's model compared the productivity of private and common property, which is modified in the present study to compare the effect of cattle rustling and migration decisions on herd size, as:

$$
\Phi=v_{i} \mathrm{CRV}+\beta_{i} P_{i}+\sum_{j=1}^{n} \alpha_{i j} \mathbf{X}_{j}+\mu_{i}
$$

where $\Phi$ is herd size; CRV represents cattle rustling variables influencing migration decision, (i.e. cattle rustling intensity and whether a herder has lost livestock to cattle rustlers in the past); $P_{i}$ is the predicted probability of migrating from Equation $4 ; \mathbf{X}_{j}$ is the vector for exogenous variables other than rustling that affect herd size; $v_{i}, \alpha_{i j}$ and $\beta_{i}$ are unknown coefficients; and $\mu_{i}$ is the stochastic disturbance term.

The present study assumed that, other things being constant, decrease in the occurrence of cattle rustling and positive perceived impact of migration would yield more herd size. Based on this assumption, the herd size model can be specified as: 
where $\mathrm{HS}^{i}$ is the herd size of herder $i$, INHERIT ${ }^{i}$ is a dummy variable representing whether or not herder $i$ inherited livestock, DOWRY ${ }^{i}$ is a dummy variable representing whether or not herder $i$ received dowry, BOUGHT ${ }^{i}$ is a dummy variable representing whether or not the herder $i$ bought livestock and $\mathrm{PRMIGR}^{i}$ is the predicted probability of migrating estimated in Equation 5. All the other variables are as defined in Equation 4 above. The independent variables used in Equations 4 and 6 of the analysis are summarized in Table 1.

\section{Statistical analysis}

STATA software (version 9.0) from StataCorp LP (4905 Lakeway Drive, College Station, Texas 77845 USA) was used to analyse the data. The estimated Equation 5 above was used in probit analysis of migratory decisions, whereas single-equation ordinary least squares (OLS) estimation was used in the determination of factors influencing herd size. Further, three-stage least square (3SLS) estimation was used to test for simultaneity in the analysis of the determinants of herd size and the results compared to those of single-equation estimation. The potential limitations to the analysis that included specification error, omitted variables, simultaneity and heteroscedasticity were taken care of using appropriate econometric procedures.

\section{Results}

The responses of the surveyed pastoralists in Baringo District of Kenya to various household characteristics are presented in Table 2. The results show that most of the households (89\%) are headed by males. In the few female-headed households (11\%), culture demands that she must consult the oldest son during decision making. Approximately $96 \%$ of the pastoralists use family labour as opposed to $4 \%$ who use hired labour. The results also indicate that more than $80 \%$ of the herders are illiterate. Some of the household heads had at one time enrolled in primary schools but latter dropped out. A few have, however, gone up to secondary school and even beyond.

Table 1 Independent variables.

\begin{tabular}{lll}
\hline Variables & Descriptions & Units \\
\hline GHH & Gender of household head & $1=$ male, $0=$ female \\
AG & Age of household head & Years \\
ED & Education level of household head & Years in school \\
HHS & Size of the household & Number \\
NCA & Number of cattle owned & Number \\
RSG & Ratio of sheep and goats to cattle & Number \\
NLI & Non-livestock income in the last 5 years & KES \\
CARUINTY & Intensity of cattle rustling & $1=$ severe, $2=$ moderate \\
LO & Type of land ownership & $0=$ common, $1=$ private \\
BC & Drought and/or diseases & Yes $=1$, no $=0$ \\
AR & Livestock lost to rustlers in the last 5 years & Yes $=1$, no $=0$ \\
INHERIT & Livestock inherited & Yes $=1$, no $=0$ \\
DOWRY & Dowry received & Yes $=1$, no $=0$ \\
BOUGHT & Livestock bought & Yes $=1$, no $=0$ \\
PRMIGR & Predicted probability of migrating & Number
\end{tabular}


Table 2 Household characteristics of the pastoralists surveyed in Baringo District, Kenya

\begin{tabular}{|c|c|c|c|c|}
\hline Description & Minimum & Maximum & Mean & SD \\
\hline Household size & 3 & 36 & 13.55 & 8.12 \\
\hline Age of household head (years) & 18 & 72 & 44.04 & 13.11 \\
\hline Number of years in school & 0 & 16 & 3.03 & 4.68 \\
\hline Number of cattle owned & 0 & 702 & 65.56 & 105.33 \\
\hline Number of shoats ${ }^{\mathrm{a}}$ owned & 0 & 3360 & 167.14 & 425.24 \\
\hline Ratio of shoats ${ }^{a}$ to cattle & 0 & 9.00 & 2.58 & 2.07 \\
\hline Non-livestock income (KES) & 0 & 840,000 & $24,167.27$ & $88,937.63$ \\
\hline Value of livestock lost to rustling (KES) & 0 & 750,000 & $90,910.00$ & $127,766.52$ \\
\hline
\end{tabular}

${ }^{a}$ Sheep and goats. KES, Kenya Shillings (80 KES = US \$1); SD, standard deviation.

\section{Determinants of pastoral migration decisions}

The practice of migration by pastoralists with their livestock is an important management strategy used by pastoral communities, aimed at exploiting available range resources. However, in recent times, cattle rustling and the insecurity generated by it have been another cause of pastoralists' migration. Table 3 presents probit model results of the determinants of migration amongst pastoral communities in Baringo District, estimated using the probability of a herder migrating. The log likelihood ratio statistics [LR chi ${ }^{2}(12)=$ 61.22] indicate that the model fits the data significantly at $1 \%$ level.

The majority of the households surveyed were headed by men (Figure 1). The findings of the present study indicate that gender of the household head is a significant determinant of migration $(P<0.1)$ (Table 3$)$. Households that are headed by males are more likely to migrate than those headed by females. In addition to gender, the age of the household head also has a negative and significant $(P<0.05)$ effect on migration. The level of education of the household head represented by the number of years in school is not a significant determinant of migration decision (Table 3). Similarly, the size of the household is also not a significant determinant of the decision to migrate.

Table 3 Determinants of the decision to migrate amongst pastoral communities in Baringo District, Kenya

\begin{tabular}{|c|c|c|c|c|}
\hline Variable & Coefficient & S.E. & $P>z$ & Effects \\
\hline Gender of household head & $0.188^{a}$ & 0.690 & 0.085 & 0.008 \\
\hline Age of household head & $-0.040^{b}$ & 0.019 & 0.035 & -0.001 \\
\hline Education level of household head & 0.015 & 0.047 & 0.741 & 0.001 \\
\hline Size of the household & 0.011 & 0.039 & 0.780 & 0.001 \\
\hline Number of cattle owned & $0.021^{b}$ & 0.010 & 0.032 & 0.001 \\
\hline Ratio of sheep and goats to cattle & -0.095 & 0.130 & 0.467 & -0.003 \\
\hline Log non-livestock income & $-0.222^{b}$ & 0.112 & 0.048 & -0.008 \\
\hline Intensity of cattle rustling & $2.207^{c}$ & 0.659 & 0.001 & 0.243 \\
\hline Type of land ownership & 0.073 & 0.675 & 0.914 & 0.002 \\
\hline Drought and/or diseases & $1.377^{\mathrm{b}}$ & 0.677 & 0.042 & 0.164 \\
\hline Livestock lost to rustlers & $0.647^{\mathrm{a}}$ & 0.493 & 0.089 & 0.030 \\
\hline Herder's perception on livestock migration & $2.415^{c}$ & 0.654 & 0.001 & 0.255 \\
\hline Constant term & -3.240 & 1.333 & 0.015 & \\
\hline Number of observations & 110 & & & \\
\hline $\operatorname{LR} \operatorname{chi}^{2}(\mid 2)$ & 61.22 & & & \\
\hline Probability $>\mathrm{chi}^{2}$ & 0.000 & & & \\
\hline Log likelihood & -25.790 & & & \\
\hline Pseudo $R^{2}$ & 0.543 & & & \\
\hline
\end{tabular}

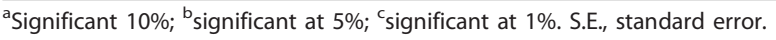




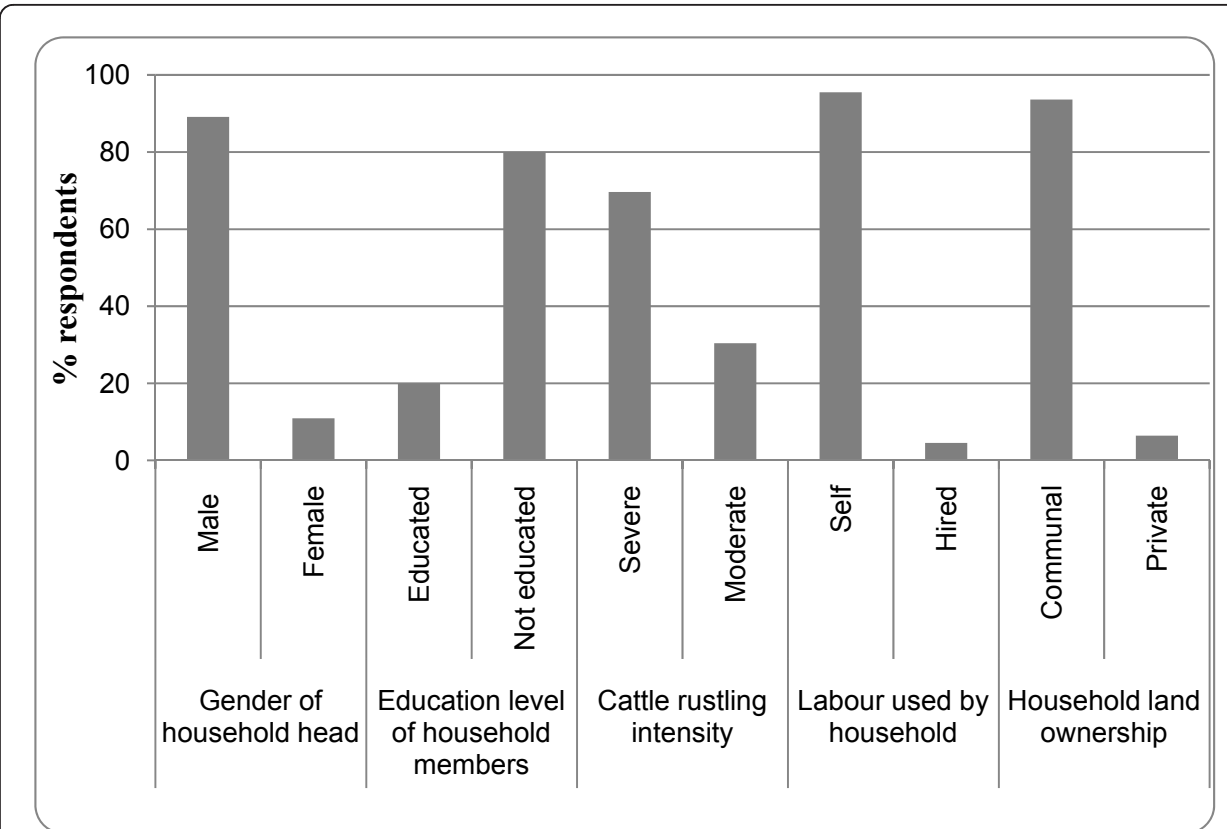

Figure 1 Percent respondents to household characteristics amongst the pastoralist sampled in Baringo District, Kenya.

The number of cattle owned by a pastoralist increases the probability of a herder migrating (Table 3 ). This is shown by the positive and significant $(P<0.05)$ impact of number of cattle on migration. The estimates indicate that increasing the number of cattle owned by pastoralists by $10 \%$ would increase the probability to migrate by approximately $0.01 \%$. On the other hand, the ratio of sheep and goats to the number of cattle has a negative coefficient. Non-livestock income has a negative and significant $(P<0.05)$ influence on migration. Increasing non-livestock income by $10 \%$ would decrease the probability to migrate by $0.08 \%$.

This study captured the influence of cattle rustling on migration by use of two dummy variables that have showed different reactions to cattle rustling occurrences. The intensity of cattle rustling influences herders' decision to migrate positively and significantly $(P<0.01)$. This implies that severe, the herders are likely to migrate with their herd to safer areas to avoid loss from cattle rustlers. Likewise, the variable on whether a herder has lost livestock to cattle rustlers also has a positive and significant $(P<0.1)$ influence on migration. Herders that have lost livestock to cattle rustlers in the past are more likely to migrate due to cattle rustling or the threat of it than those who have not lost livestock before. The migration decision caused by factors related to cattle rustling is taken as a form of insurance against the vice.

The majority of the pastoralists in Baringo District own land on a communal basis. However, results indicate that this type of land ownership is not an important determinant of the decision to migrate (Figure 1 and Table 3). On the other hand, loss of livestock to drought and/or diseases or any other biophysical factor has a positive and significant $(P<0.05)$ effect on migration. Herders that have lost livestock to drought and/or diseases before are more likely to migrate in search of water and pasture or flee from diseases and insecurity than their counterparts who have not. Besides, herders' 
perception of livestock migration influences migration decision positively and significantly $(P<0.01)$. Herders that perceive migration positively are more likely to migrate for whichever reason than those who perceive it negatively.

\section{Determinants of pastoral herd size}

The impacts of cattle rustling, migration and other socioeconomic factors were tested through their influence on herd sizes. The results of the single-equation estimation of herd size is presented in Table 4 while the three-stage least squares (3SLS estimation of herd size is presented in Table 5. The results for both single-equation estimation and 3SLS methods are compared very closely, indicating that there is no simultaneity. The Chow tests ( $F$ statistics) for all the specification confirm the goodness of fit of the model and confirm the stability of the coefficients to changes in specification.

Results on estimation of herd size indicate that gender of the household head has a positive and significant $(P<0.1)$ influence on herd size, which means that households that are headed by males are more likely to keep larger herds than those headed by females. Moreover, the age of the household head positively and significantly $(P<0.1)$ influences the herd size, such that elderly household head are more likely to keep bigger herds than their younger counterparts. The level of education has a negative and significant $(P<0.1)$ influence on herd size, suggesting that herders with higher education levels are more likely to keep fewer numbers of livestock than those with lower education levels. Similarly, the size of the household has a significant $(P<0.01)$ but positive impact on herd size. This implies that large households own larger herd sizes than small households.

Non-livestock income exerts a strong negative and significant $(P<0.01)$ impact on herd size. There is an inverse relationship such that when non-livestock income

Table 4 Single-equation regression analysis for herd size determinants amongst pastoral communities in Baringo District, Kenya

\begin{tabular}{|c|c|c|c|c|}
\hline Variables & Coefficient & S.E. & $z$ & $P>Z$ \\
\hline Gender of household head & $0.214^{\mathrm{a}}$ & 0.124 & 1.72 & 0.089 \\
\hline Age of household head & $0.007^{a}$ & 0.004 & 1.87 & 0.065 \\
\hline Education level of household head & $-0.017^{a}$ & 0.008 & -1.97 & 0.051 \\
\hline Size of the household & $0.024^{c}$ & 0.006 & 4.11 & 0.002 \\
\hline Log non-livestock income & $-0.070^{c}$ & 0.019 & -3.66 & 0.001 \\
\hline Intensity of cattle rustling & $-0.001^{b}$ & 0.093 & -0.01 & 0.039 \\
\hline Type of land ownership & 0.029 & 0.162 & 0.18 & 0.858 \\
\hline Drought and/or diseases & $-0.184^{\mathrm{a}}$ & 0.167 & -1.10 & 0.075 \\
\hline Livestock lost to rustlers & -0.001 & 0.084 & -0.00 & 0.997 \\
\hline Livestock inherited & $0.436^{\mathrm{b}}$ & 0.172 & 2.54 & 0.013 \\
\hline Dowry received & 0.086 & 0.094 & 0.92 & 0.362 \\
\hline Livestock bought & 0.116 & 0.080 & 1.45 & 0.149 \\
\hline Predicted probability of migrating & $0.436^{c}$ & 0.161 & 2.70 & 0.008 \\
\hline Constant term & 0.316 & 0.258 & 1.23 & 0.223 \\
\hline Number of observations & 110 & & & \\
\hline$F(13,96)$ & 7.18 & & & \\
\hline Probability $>F$ & 0.000 & & & \\
\hline R-squared & 0.493 & & & \\
\hline Adjusted R-squared & 0.424 & & & \\
\hline RMSE & 0.383 & & & \\
\hline
\end{tabular}

${ }^{a}$ Significant at $10 \%$; ${ }^{b}$ significant at $5 \%$; ${ }^{c}$ significant at $1 \%$. S.E., standard error. RMSE, root mean square error. 
Table 5 Three-stage least squares regression analysis for herd size determinants amongst pastoral communities in Baringo District, Kenya

\begin{tabular}{lcccc}
\hline Variables & Coefficient & S.E. & $\boldsymbol{z}$ & $\boldsymbol{P}>\mathbf{z}$ \\
\hline Gender of household head & $0.212^{\mathrm{a}}$ & 0.116 & 1.83 & 0.068 \\
Age of household head & $0.006^{\mathrm{b}}$ & 0.003 & 1.98 & 0.048 \\
Education level of household head & $-0.018^{\mathrm{b}}$ & 0.008 & -2.11 & 0.035 \\
Size of the household & $0.024^{\mathrm{c}}$ & 0.005 & 4.41 & 0.001 \\
Log non-livestock income & $-0.070^{\mathrm{c}}$ & 0.018 & -3.90 & 0.001 \\
Intensity of cattle rustling & $-0.003^{\mathrm{b}}$ & 0.087 & -0.04 & 0.471 \\
Type of land ownership & 0.031 & 0.151 & 0.20 & 0.840 \\
Drought and/or diseases & $-0.186^{\mathrm{a}}$ & 0.156 & -1.19 & 0.083 \\
Livestock lost to rustlers & -0.001 & 0.079 & -0.01 & 0.989 \\
Livestock inherited & $0.438^{\mathrm{c}}$ & 0.160 & 2.74 & 0.006 \\
Dowry received & 0.089 & 0.088 & 1.01 & 0.311 \\
Livestock bought & 0.115 & 0.074 & 1.55 & 0.122 \\
Predicted probability of migrating & $0.427^{\mathrm{c}}$ & 0.151 & 2.84 & 0.005 \\
Constant term & 0.316 & 0.241 & 1.31 & 0.190 \\
Observations & 110 & & & \\
Probability $>F$ & 0.000 & & & \\
RMSE & 0.358 & & & \\
R-squared & 0.49 & & & \\
Chi & 106.78 & & & \\
\hline
\end{tabular}

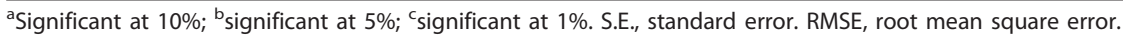

increases by $10 \%$, herd size is likely to decreases by $0.7 \%$. Also, cattle rustling intensity has a negative and significant $(P<0.05)$ influence on herd size, indicating that whenever cattle rustling intensity moves towards severity, the pastoralists are more likely to reduce their herd size. Similarly, though not significant, the coefficient for livestock lost to cattle rustlers is negative in determination of the herd size. The predicted probability of migrating has a significant $(P<0.01)$ positive influence on herd size, suggesting that herders who migrate are likely to have larger numbers of livestock than those who do not migrate.

Drought and diseases influences herd size negatively. This is shown by the significant $(P<0.1)$ influence the coefficient of drought and diseases has on herd size (Table 4$)$, implying that those that have lost livestock to drought and diseases previously are more likely to own smaller herds than those not affected. In contrast, livestock inheritance showed a very significant $(P<0.01)$ and positive influence on herd size. Herders who have inherited livestock are likely to have larger herds than those who have not. Furthermore, results indicate that the majority of households have at one time or another inherited livestock from their relatives. On the contrary, both dowries received and livestock bought did not significantly influence pastoralists' herd size.

\section{Discussion}

Determinants of pastoral migration decisions

The observation in the present study where male-headed households are more likely to migrate is in agreement with the traditional/cultural norms of most African pastoralists that allocate the responsibility to decide where to locate the household to the husband. These results are also consistent with the traditional model of household decision making reported by (Doss and McPeak (2005)), where husbands make decisions about herd 
management, in the best interest of the herd and family. However, the decision to migrate varies with ages of the household head, such that younger household heads are more likely to make migratory decisions compared to older heads. These results are in agreement with those of (Kabubo-Mariara (2002)), who reported that elderly people face less chances of migrating, implying they are less likely to migrate than their younger counterparts.

Results from the present study indicate that the household head's level of education and the size of the household are not a significant determinant of migration decision. It is probable that the causes of migration may be affecting all households, regardless of the level of education of the heads and household sizes. The observation that pastoralists owning large numbers of cattle are more likely to migrate than those with fewer numbers (Table 3) may be due to the faster depletion of resources (pastures and water) in a particular locality by the large numbers of animals, thus necessitating the need to migrate in search of resources elsewhere. Other reports indicate that households with smaller herds are better placed to temporarily send cattle to relatives/ friends during times of crises so that they do not have to migrate (Kabubo-Mariara 2003). However, the negative coefficient in the ratio of sheep and goats to that of cattle (Table 3 ) suggests that pastoralists with more sheep and goats than cattle are less likely to migrate. This could be attributed to the better adaptation of sheep and goats to hash climatic conditions than cattle, hence less need for migration in search of range resources. In addition, small ruminants are not as fast as cattle in terms of mobility and take more time during migration, which is a limitation in case the herders are being pursued or are intending to move for long distances. As a result, it is easier and faster to migrate with cattle than with sheep and goats.

Pastoralists engaged in non-livestock income-generating activities are less likely to migrate (Table 3), probably because they keep fewer and a manageable number of livestock than those entirely relying on livestock production for their livelihood. Such diversification of income sources by pastoralists has been observed before. (Little et al. (2001)) reported that pastoralists engage in non-livestock activities not only to supplement consumption needs but also to buttress against risky shocks caused by climatic fluctuations, animal disease, market failures and insecurity. In Baringo, pastoralists engage in activities such as crop farming, honey harvesting, formal and informal employment. However, although cultivation is seen by some as a viable risk management strategy ((Campbell 1984; Smith 1998)), others view it as unsustainable and destructive option that even accentuates risk ((Hogg 1987; Hogg 1988)).

Generally, livestock migration by pastoralists has mainly been in search of range resources (water and pasture). However, another type of migration has emerged, where herders migrate to safer areas due to the intensity of cattle rustling/raiding or in fear of attack by rustlers (Table 3). Earlier, (Mkutu (2000)) noted that whenever droughts that cause scarcity of pasture and water, deplete a community's herd, they seek to replenish their stock through raiding. Thus, the insecurity associated with raiding leads to migration and the escape may involve long or short distances, depending on the information available about the level of insecurity and the availability of resources ((Young et al. 2005)). The route followed and the length of stay will depend on the intensity of the rustling. It is known that cattle rustling leads to loss of livestock, destruction of property, and injury and sometimes death of people, which are the main 
reasons that make herders migrate to safer places ((Hendrickson et al. 1996; Mkutu 2006)). In Kenya, cattle rustling has reached unprecedented proportions in the recent past. It has changed in nature, scale and dimension due to a number of factors, including the proliferation of small arms in the region, the commercialization of raiding, high unemployment in pastoral areas, frequent droughts and reduced respect for traditional conflict-solving mechanisms (CEWARN 2005).

Other than cattle rustling, there are other factors such as droughts and diseases that influence the decision to migrate. Unlike cattle rustling where some members of the community may be able to escape attacks by virtue of sheer luck, droughts and diseases affect the community entirely and in the same magnitude. Herders will therefore migrate to escape droughts and diseases due to fear of loss. (Little et al. (2001)) points out that to avoid loss of livestock through drought, pastoralists migrate in search of pastures and water. In other cases, the cycle of movement is determined not only by availability of pasture and water but also by the varying seasonal patterns of disease (Raikes 1981). The present observation where the type of land ownership is not a significant determinant of migration decisions may be attributed to most pastoralists in Baringo not having individual ownership of land but rather depending on communal lands. In such communal lands, available resources are exploited through migration from one locality to another.

The herder's perception of livestock migration is quite important in determining the decision to migrate. Those who perceive migration positively see it as a better means of survival for the livestock (Kabubo-Mariara 2003). The pastoralists in Baringo District, particularly the Pokot community, usually migrate in search of pasture and water during the dry season (January to March). Other factors may also influence the decision to migrate with livestock. Such factors include environmental degradation (Kabubo-Mariara 2005) and the desire to fallow the land to allow soil and vegetation to recover (Ahuja 1998).

\section{Determinants of pastoral herd size}

The observation that the gender of the household head influences herd size (Tables 4 and 5) may imply male-headed households are more likely to own larger herds of livestock than female-headed households, possibly because they shoulder more household responsibilities and hence the need for more livestock. Moreover, livestock plays several roles in smallholder systems such as dowry payments, status, initiation, ceremonial purposes and also as living "savings" (Ouma et al. 2003). In the traditional African context, it is the males who are expected to pay bride price (paid to the bride's family), initiation and other ceremonial occasions. Men also have a right to marry more than one wife, increasing the need for livestock to pay dowry. These expectations may be compelling men to engage in cattle rustling activities in order to replenish (after loss) or increase their herds (Mkutu 2000).

The mean number of cattle over household size is 4.88 (Table 2), with a median of 3.5. This herd size appears to be high and could be due to decreases in household size associated with the tendency towards monogamy, as well as improved livestock disease control services resulting in increase in animal numbers. Elderly household heads are more likely to keep larger herds than younger heads, probably because the elderly have a deep-rooted "cattle complex" culture where numbers of animals are often more 
important than the value they command. Also, the elderly, due to their age, have had the opportunity to accumulate livestock over time and, because of their attachment to their animals, have not disposed of them. On the other hand, the younger household heads are still in the process of accumulating their herds. (Livingstone (1977)) cited a number of contemporary adherents to the view of economic irrationality among the Pokot men (household heads), by equating wealth to animals owned and in the process accumulating a lot of animals, especially cattle.

Household heads with higher education level are more likely to keep fewer numbers of livestock than those with lower level of education or no education at all. This is probably because educated household heads are more likely to engage in other income-generating activities and as such may not be able to keep large numbers of animals that require more attention. Also, educated household heads are likely to have their children attending school, meaning they are faced with shortage of labour to look after livestock. Besides, educated household heads are likely to make use of market information and sell their animals for commercial purposes or for other reasons such as school fees.

The results of the present study that show the size of the household influencing herd size (Tables 4 and 5) suggest that large households are likely to own bigger herds of livestock than smaller households. Traditionally, large households indicate adequate availability of family labour necessary to look after large herd sizes. The large number of family members in a household may be a result of the head marrying many wives, and in order to pay the dowry for all the wives, he should have a large number of livestock. This is in agreement with the suggestions by (Ahuja (1998)) and (Kabubo-Mariara (2002)) that wealthy husbands owned large herds of livestock.

The negative correlation between non-livestock income and herd size suggests that pastoralists generating income from activities outside livestock rearing are likely to keep smaller herds of animals. This is perhaps an indication that herders may not invest their non-livestock income into increasing their herd size. It could also imply that livestock might be sold in order to invest in other non-livestock activities. As explained previously, pastoralists may reduce their herd for various reasons, including dowry payment, fear of losing animals to insecurity and other household needs such as food, school fees, medical treatment, etc.

The intensity and frequency of cattle rustling inversely affects the herd size of pastoralists, as it often leads to loss of livestock. This is an indication that herders that have lost livestock in previous attacks are more likely to keep smaller herds for fear of other attacks. Thus, the threats generated by the activities of cattle rustling influences decision making by pastoralists, a view supported by (Hendrickson et al. (1996)) and (Mkutu (2006)). Though not significantly influencing herd size, the coefficient for livestock lost to cattle rustlers suggest that it has far-reaching repercussions on herders' decision-making process. For example, if a herder decides to migrate in fear of attack or as a result of an attack by cattle rustlers, he/she might not be concerned about pasture and water availability or death of livestock due to diseases.

Droughts and diseases often lead to loss of livestock, thus reducing herd size. Nevertheless, unlike cattle rustling where once a raid has occurred there is constant threat of additional raids, successive droughts are typically separated by a return of rainy periods, even though brief at times, which helps to regenerate pasture and allow 
pastoralists time for the next period of stress (Hendrickson et al. 1996). The predominant communal land ownership in the study area enables equal access and utilization of available resources (e.g. pasture and water). Households are therefore not restricted to keeping a particular livestock herd size. Consequently, the type of land ownership is not a significant determinant of herd size.

The significant positive relationship between livestock inheritance and herd size noted in this study (Tables 4 and 5) suggests herders who have inherited livestock are likely to have larger herds than those who have not. In the culture of this group of pastoralists, a man's ownership of livestock starts at birth, where the father gives the child at least one female animal often symbolized by tying his navel cord to the animal soon after being born, and thereafter his herd builds up. Amongst the Somali pastoralist community, this practice is known as wahad (Guliye et al. 2007). Both dowry received and livestock bought by the pastoralists are not significant determinants of herd size. This is because as much as the pastoralists receive dowry when their daughters get married, they are also expected to pay the same as bride price when their male family members are getting married. Thus, although livestock is gained through dowry, it is also lost as bride price. Similarly, the sale of livestock for various household needs counteracts any increase in herd size resulting from purchase of animals.

Herders who perceive migration positively and migrate with their livestock are in a better position to access more pasture and water and avoid livestock losses through drought and diseases. Indeed, (Little et al. (2001)) note that herders who migrate with their herd, where mobility remains the key pastoral risk management strategy, have considerably fewer livestock loses during climatic disasters than their sedentary counterparts. Through migration, herders may also be able to avoid insecurities brought about by cattle rustling.

\section{Conclusions and implications}

This study intended to elucidate the effects of cattle rustling and other household characteristics on migration decisions and herd size amongst the pastoralists in Baringo District in Kenya. Gender and age of the household head are important determinants of the decision to migrate and herd size. Households headed by younger males are more likely to make migratory decisions. Also, the ownership of large number of cattle and the occurrence of droughts and diseases influences pastoralists' decision to migrate. However, the engagement in non-livestock income-generating activities reduces the possibility of migration.

Male-headed households are more likely to keep larger herds of livestock, whereas household heads with higher level of education are more likely to keep smaller herd sizes. Also, households with bigger family sizes and those that have inherited livestock are more likely to own larger herds of livestock. However, generation of income outside livestock rearing by the pastoralists leads to the keeping of smaller herds of animals. The intensity and frequency of cattle rustling inversely affects the herd size of pastoralists. Droughts and diseases often lead to loss of livestock, thus reducing herd size, and therefore influence the decision to migrate so as to avoid loss of animals.

In general, the practice of cattle (livestock) rustling, which is quite rampant amongst pastoralist communities in Kenya (sometimes occurring across borders), destabilises communities, such that they are not able to pursue their normal livelihood strategies 
and thus may be contributing to increased poverty. Policies pursued by successive governments have failed to contain this menace, perhaps because the traditional conflictsolving institutions have been undermined by the creation of administrative structures that are not subject to traditional institutions. Besides, the high unemployment and rising poverty levels amongst pastoral communities are fuelling cattle rustling. Increasing the level of development in pastoral areas may help in reducing the problem. Formulation of appropriate policies, achieved through an all-inclusive consultative process, coupled with improved infrastructures (schools, alternative sources of income, security, etc.) will be a key to controlling the cattle rustling menace. Such policies should not only aim at improving existing livelihood sources mainly based on livestock but also provide alternative livelihood strategies so as to achieve food security. Further participatory research (that includes the pastoralists) needs to be conducted to determine the trends of cattle rustling, achievements made by any previous interventions and other feasible remedial measures to combat cattle rustling and related insecurity.

\section{Acknowledgements}

The authors thank most sincerely all those pastoralists interviewed in Baringo District for their time and willingness to share their experiences on such an emotive subject of cattle rustling.

\section{Author details}

${ }^{1}$ Department of Business Administration, Chuka University College, P. O. Box 109-60400 Chuka, Kenya ${ }^{2}$ Department of Agricultural Economics and Agri-business Management, Egerton University, P. O. Box 536-20115, Egerton, Kenya ${ }^{3}$ Department of Animal Sciences, Egerton University, P. O. Box 536-20115, Egerton, Kenya ${ }^{4}$ Current Address:

Department of Agribusiness Management and Trade, Kenyatta University, P.O. Box 43844-00100, Nairobi, Kenya

\section{Authors' contributions}

All authors participated in collecting data. GKK and AYG drafted the manuscript. All authors read and approved the final manuscript.

\section{Authors' information}

AYG is a Senior Lecturer in Animal Production and Nutrition in the Department of Animal Sciences, Egerton University (Kenya), and is also the current Chairman of Kenya Camel Association. GKK is a Lecturer in Agricultural Economics in the Department of Business Administration, Chuka University College (Kenya). BKN is an Associate Professor of Agribusiness Management in the Department of Agribusiness Management and Trade, Kenyatta University (Kenya).

\section{Competing interests}

The authors declare that they have no competing interests.

Received: 24 April 2011 Accepted: 20 October 2011 Published: 20 October 2011

\section{References}

Adams, J. 1999. Management of risk and uncertainty. London: Adam Smith Institute. http://www.adamsmith.org/. Accessed 2 November 2007.

Ahuja, V. 1998. Land degradation, agricultural productivity and common property: Evidence from Cote d'Ivoire. Environment and Development Economies 3: 7-34. doi:10.1017/\$1355770X98000023.

Behnke, RH, and I Scoones. 1993. Rethinking range ecology: implications for rangeland management in Africa. In Range ecology at disequilibrium: New models of natural variability and pastoral adaptation in African Savannas, ed. Behnke RH, Scoones I, Kerven C. London: Overseas Development Institute.

Campbell, DJ. 1984. Responses to drought among farmers and herders in Southern Kajiado District, Kenya. Human Ecology 12(1): 35-63. doi:10.1007/BF01531283.

Caselton, WF, and W Luo. 1992. Decision theory with imprecise probabilities: Dempster-Shafer theory and application. Water Resources Research 28: 3071-3083. doi:10.1029/92WR01818.

CEWARN. 2005. The conflict early warning and response (CEWARN) mechanism. Inter-governmental Authority on Development (IGAD). http://www.cewarn.org/index.php?option=com_docman\&task=doc_details\&gid=73\&ltemid=87. Accessed 10 June, 2009.

Dietz, T. 1987. Pastora1ists in dire straits; Survival strategies and external intervention in a semi-arid region at the Kenya/ Uganda border; Western Pokot, 1900-1986. Nederlanse Geograjische Studies No 49, University of Amsterdam.

Doss, CR, GJ McPeak, and CB Barrett. 2008. Interpersonal, intertemporal and spatial variation in risk perceptions: Evidence from East Africa. World Development 36(8): 1453-1468. doi:10.1016/j.worlddev.2007.06.023.

Doss, CR, and GJ McPeak. 2005. Are household decisions cooperative? Evidence on pastoral migration and milk sales from northern Kenya. Economic Growth Centre, Yale University, Centre Discussion Paper No. 906. http://www.econ.yale.edu/ growth_pdf/cdp906.pdf. Accessed 22 October 2007. 
Ducey, MJ. 2001. Representing uncertainty in silvicultural decisions: An application of Dempster-Shafer theory of evidence. Journal of Forest Ecology and Management 150: 199-211. doi:10.1016/S0378-1127(00)00565-X.

FAO. 2004. Livestock sector brief Kenya. Food and Agriculture Organization (FAO) Report. http://www.fao.org/. Accessed 14 November 2007

Guliye, AY, IM Noor, BO Bebe, and IS Kosgey. 2007. The role of camels (Camelus dromedarius) in the traditional lifestyle of the Somali pastoralists in the arid and semi-arid areas of northern Kenya. Outlook on Agriculture 36(1): 29-34. doi:10.5367/ 000000007780223669

Hendrickson, D, J Armon, and R Mearns. 1996. Livestock raiding among the pastoral Turkana of Kenya: Redistribution, predation and the links to famine. Institute of Development Studies Bulletin 27(3): 17-30.

Hogg, R. 1987. Development in Kenya: Drought, desertification and food Scarcity. African Affairs 86(1): 47-58.

Hogg, R. 1998. Water harvesting and agricultural production in semi-arid Kenya. Development and Change 19(1): 69-87.

Kabubo-Mariara, I. 2002. Rural poverty, property rights and environmental resource management in Kenya. African Journal of Environmental Assessment and Management 6(1): 1-15.

Kabubo-Mariara, I. 2003. The linkages between property rights, migration and productivity: the case of Kajiado District, Kenya. Environmental and Development Economics 8: 621-636. doi:10.1017/S1355770X0300330.

Kabubo-Mariara, I. 2005. Herders response to acute land pressure under changing property rights: Some insights from Kajiado District, Kenya. Environment and Development Economics 10(1): 67-85. doi:10.1017/S1355770X04001512.

Little, PD, K Smith, BA Cellarius, CB Coppock, and C Barrett. 2001. Avoiding disaster: Diversification and risk management among East African herders. Development and Change 32(3): 401-433. doi:10.1111/1467-7660.00211.

Livingstone, I. 1977. Economic irrationality among pastoralists. Development and Change 3: 209-230.

Mkutu, K. 2000. Cattle rustling and the proliferation of small arms: The case of Baragoi division, Samburu district in Kenya. African Peace Forum on Improving Human Security through the Control and Management of Small Arms, Africa Peace Forum/International Resource Group (APFO/RG), Nairobi.

Mkutu, K. 2006. Small arms and light weapons among pastoralist groups in the Kenya-Uganda border area. African Affairs 106(422): 47-70. doi:10.1093/afraf/adl002.

Okoti, M, JC N'gete, WN Ekaya, and DM Mbuvi. 2004. Land use, ecology and socio-economic changes in pastoral production system. Journal of Human Ecology 16(2): 83-89.

Ouma, EA, GA Obare, and SJ Staal. 2003. Cattle as assets: assessment of non-market benefits from cattle in smallholder Kenyan crop-livestock systems. Contributed paper to the 25th International Association of Agricultural Economists (IAAE) Conference, Durban, South Africa.

Raikes, PL. 1981. Livestock development and policy in East Africa. Uppsala: Scandinavian Institute of African Studies.

Shafer, G. 1976. A mathematical theory of evidence. Princeton: Princeton University Press.

Smith, K. 1998. Sedentarization and market integration: New opportunities for Rendille and Ariaal women of Northern Kenya. Human Organization 57(4): 459-468.

SRA. 2003. Strategy to revitalize agriculture (SRA). Republic of Kenya, Government Printer, Nairobi.

Young, H, AM Osman, Y Aklilu, R Dale, B Badri, and Al Fuddle. 2005. Darfur livelihoods under siege; executive summary and recommendations. Feinstein International Famine Center, Tufts University, Medford, MA, USA http://www.sarpn.org/ documents/d0001277/PNADC475_Darfur_Febr2005.pdf. Accessed 17 September 2007.

doi:10.1186/2041-7136-1-18

Cite this article as: Kaimba et al.: Effects of cattle rustling and household characteristics on migration decisions

and herd size amongst pastoralists in Baringo District, Kenya. Pastoralism: Research, Policy and Practice 2011 1:18.

\section{Submit your manuscript to a SpringerOpen ${ }^{\odot}$ journal and benefit from:}

- Convenient online submission

- Rigorous peer review

- Immediate publication on acceptance

- Open access: articles freely available online

- High visibility within the field

- Retaining the copyright to your article

Submit your next manuscript at $\gg$ springeropen.com 